\title{
The Effect of Financial Literacy, Financial Inclusion and Financial Attitude on Saving Behavior with Self Control as Moderation: Study on Households in Cingkes Village, Dolok Silau District, Simalungun Regency
}

\author{
Naca Perangin-angin ${ }^{1}$, Khaira Amalia Fachrudin ${ }^{2}$, Nisrul Irawati ${ }^{3}$ \\ ${ }^{1,2,3}$ Faculty Economics and Business, University of Sumatera Utara, Medan, Indonesia. \\ Corresponding Author: Naca Perangin-angin
}

DOI: https://doi.org/10.52403/ijrr.20220153

\begin{abstract}
Saving can be used as an investment for most people today considering the diverse needs of each person. Conditions of uncertainty make people aware that saving is a solution to prepare for future crises that may be higher. Saving is done by the general public in the hope of saving and setting aside a portion of the income that can be used for future needs. The purpose of this study was to determine and analyze the effect of financial literacy, financial inclusion, and financial attitude on saving behavior with self control as moderation. The data used are primary data obtained directly from respondents, amounting to 90 respondents. The sampling method used is probability sampling, with a sampling technique that is Simple Random Sampling. Questionnaires that have been filled out by respondents are analyzed by quantitative analysis methods, then used smartPLS is used as an analytical tool. The results of this study indicate that financial literacy has an insignificant effect on saving behavior, financial inclusion has no significant effect on saving behavior, financial attitude has a positive and significant effect on saving behavior and self control is not significant as a moderator of the relationship between financial literacy, financial inclusion and financial attitude towards saving. behavior.
\end{abstract}

Keywords: Financial Literacy, Financial Inclusion, Financial Attitude, Self Control, Saving Behavior
INTRODUCTION

The COVID-19 pandemic in Indonesia has not ended since March 2019 which resulted in people having to adapt to the situation. Usually people do activities outside the home, but in the current situation, people must minimize activities outside the home. Governments in various regions have also made a series of rules to minimize the rate of transmission of COVID-19 by implementing various policies. The COVID19 pandemic has greatly affected the economy of both businesses and society. The pandemic has become a valuable lesson that has made people aware of the uncertain conditions that need to be faced with financial preparation. Saving and investing can protect the value of money from inflation so that people's purchasing power can survive in the future. Saving can be used as an investment for most people today considering the diverse needs of each person. Saving is also important for prosperity in the future when you are no longer able to work, no longer earn an income, and saving can train yourself to be thrifty and independent. This can affect in a long time, if someone does not have savings, there is no reserve fund used to meet emergency needs, so that it will lead to dependence on others (Wardani \& Susanti, 2019). 
Naca Perangin-angin et.al. The effect of financial literacy, financial inclusion and financial attitude on saving behavior with self control as moderation: study on households in Cingkes Village, Dolok Silau District, Simalungun Regency.

The majority of the people of Cingkes Village, Dolok Silau District, Simalungun Regency, make a living as farmers. The problem often faced by farmers is that there are different patterns of income and expenditure flows, where income depends on the harvest period while spending almost every day has to be done such as household needs, buying pesticides and fertilizers for plants. This is certainly a problem for households, making it difficult to implement good financial management. Households have the motivation to save which can be used as an emergency fund in case of unexpected events in the future. In general, individuals and households do not save enough in the context of short-term savings but must have long-term savings for old age.

Based on previous research, there are many factors that influence saving behavior. The first factor that is thought to influence household saving behavior is financial literacy. Financial literacy is the understanding, insight and basic financial skills needed for successful financial management needs to avoid financial problems in the future (Sekarwati \& Susanti, 2020). Financial literacy that is instilled in the community early on will help the community, especially households, so that households understand how to manage finances well so that households can set aside their income to save for the future or household emergency funds.

Financial Inclusion is a program intended to make the public understand and use the services of financial institutions, especially banking (Kumar, 2013). Financial inclusion itself is defined as a person's ability to access various financial service products that are affordable and in accordance with their needs. This ability is mainly related to a complex understanding that includes financial awareness, knowledge of banks and banking networks as well as knowledge of various facilities provided by the banking world. A person's financial attitude will help individuals determine their attitudes and behavior in terms of finance, both in financial management, personal financial budgeting or how individual decisions regarding the form of investment to be taken (Budiono, 2015). A good financial management attitude begins with applying a good financial attitude. In general, when someone wants to decide to save or consumptive, in making decisions, individuals tend to combine emotions in decision making. The better a person's attitude or mentality, the better the behavior in making decisions.

Self-control is related to the technique or way of individuals in regulating emotions and impulses for action that is within themselves and involves the ability to manipulate themselves to increase or decrease their behavior every time they make decisions (Ardiana, 2016). Self control has an important role in determining and directing the behavior of each individual, including financial behavior, both consumptive behavior or saving behavior as well as someone's behavior in managing their finances. Self-control refers to efforts to rule out or change unwanted behavior so that it can withstand temptations or desires that suddenly arise because they have previously set goals and always monitor every action so that goals are achieved. The problem in this study is the lack of mobilization of household savings in Cingkes Village while public spending has decreased during the pandemic and the low proportion of Cingkes Village households saving in banking institutions. There is still a research gap towards several studies regarding the variables to be studied in this study.

\section{LITERATURE REVIEW Saving Behavior}

In an economic context, saving is defined as the residual income after deducting current consumption over a certain period of time. Conversely, saving in a psychological context is called the process of not spending money in the current period and will be used in the future (Sirine \& Utami, 2016). Saving is a person's effort to set aside money to face the future and to get 
Naca Perangin-angin et.al. The effect of financial literacy, financial inclusion and financial attitude on saving behavior with self control as moderation: study on households in Cingkes Village, Dolok Silau District, Simalungun Regency.

relatively large amounts of money. In other words, saving behavior is a picture of a person whether he chooses to save or not to save. Saving behavior is related to one's responsibility related to the way of financial management in which part of the money is set aside to be saved for future goals. Saving behavior is a combination of the perception of future needs, savings decisions and savings actions (Thung et al., 2012).

\section{Financial Literacy}

Financial literacy emphasizes the importance of applying knowledge and skills in finance in making financial decisions (Atkinson \& Messy, 2011). Financial knowledge is a person's intelligence and ability to manage his finances (Laily, 2016). According to Garman and Forgue (2010), financial literacy is knowledge of facts, concepts, principles, and technology so that everyone is smart about money. Someone who has financial literacy can improve a person's ability to deal with everyday financial problems and help in making financial decisions. Financial literacy is a combination of awareness, knowledge, behavioral skills, and habits needed to make the right financial decisions and ultimately achieve a satisfactory financial condition.

\section{Financial Inclusion}

Financial Inclusion is the provision of access to financial services for the entire population, especially the poor and other isolated populations (Ozili, 2018). Everyone has the right to get access and full services from financial institutions in a convenient, informative, affordable and timely manner, without discrimination and full respect for their dignity. Financial inclusion is the delivery of financial services, including banking and credit services, at an affordable cost to a large section of disadvantaged and low-income groups who tend to be excluded. Various financial services including access to savings, loans, insurance, payments and remittance facilities offered by the formal financial system (Dixit, 2013). Financial inclusion is all efforts aimed at eliminating all forms of price and non-price barriers to public access to financial services. This inclusive finance is a national strategy to encourage economic growth through income distribution, poverty alleviation and financial system stability (Indonesia, 2016).

\section{Financial Attitude}

Pankow (2003) defines financial attitude as a state of mind, opinion and judgment about finances (Herdjiono \& Damanik, 2016). Attitude refers to how a person feels about personal financial matters, which is measured by the response to a statement or opinion (Marsh, 2006). Financial Attitude owned by a person will help the individual in determining attitudes and behavior in financial matters, both in terms of financial management, personal financial budgeting, or how the individual's decisions regarding the form of investment to be taken. Every individual who always applies a financial attitude in his life will make it easier for the individual to determine his attitude and behavior in financial matters. Attitude has 3 (three) main components consisting of (Budiono, 2015): 1. Cognitive is an opinion or belief of an attitude that determines the level for something or a more important part of the attitude. 2. Affective (Feeling) is an emotional that resides within each individual. Feelings are also interpreted as a statement of the attitude taken and determine the behavior that will be taken by each individual. 3. Behavior or action is a reflection of how individuals behave in something or someone.

\section{Self Control}

Self control is an individual skill in sensitivity to reading the situation of oneself and the environment. In addition, it is also the ability to control and manage behavioral factors according to situations and conditions to present themselves in socializing the ability to control behavior, the tendency to attract attention, the desire 
Naca Perangin-angin et.al. The effect of financial literacy, financial inclusion and financial attitude on saving behavior with self control as moderation: study on households in Cingkes Village, Dolok Silau District, Simalungun Regency.

to change behavior to suit others, please others, always conform with others. others, and cover up their feelings (Ghufron \& Rini, 2012).

Self-control is a person's action to control automatically habits, drives, emotions, and desires with the aim of directing his behavior (DeLisi \& Berg, 2006). Self-control is the willingness to delay gratification, the willingness to carry out activities even though it does not immediately produce satisfaction, the willingness to be careful and brave to face risks and see the positive side of failure (Lusardi \& Mitchell, 2011). Rodin states that self-control is a feeling that a person can make decisions and take effective actions to produce the desired results and avoid unwanted consequences. Meanwhile, according to Berk, self-control is an individual's ability to resist momentary desires or impulses that are contrary to behavior that is not in accordance with social norms (Khairuni, 2016).

\section{MATERIALS \& METHODS}

The type of research used in this research is quantitative research with a descriptive approach. Quantitative research method is one type of research whose specifications are systematic, well-planned and clearly structured from the beginning to the making of the research design. This research was conducted in Cingkes Village, Dolok Silau District, Simalungun Regency with the research subject being Cingkes Village households. The measurement of saving behavior, financial inclusion, financial attitude and self-control variables in this study is using a Likert scale. The population in this study was Cingkes
Village, Doloksilau District, Simalungun Regency as many as 920 members (husband/wife) of the household. In this study, the population is known for certain, so to be able to find a sample is to use the Slovin formula, the Slovin formula is used to determine the sample size of the population that has a known number of 920 households. For the level of precision specified in the determination of the sample is $10 \%$. Based on the Slovin formula, the sample obtained is 90 members (husband/wife) of the household. Primary data that has been successfully collected in this study, will be analyzed using quantitative analysis methods, namely analysis that uses numbers and statistical calculations to analyze a hypothesis. While the analytical tool used is smartPLS (Partial Least Square) to test the relationship between variables.

\section{RESULT \\ Respondents' Descriptive Results}

Based on the characteristics of the respondents, it is known that respondents aged 29 to 34 years are more dominant, namely as many as 23 respondents and the household finance manager in this study is the wife's dominant manager. Characteristics of respondents based on education, it is known that the respondents in this study are high school dominant as many as 51 respondents and based on occupation it is known that the dominant respondents are farmers.

\section{Data Analysis Results}

The results of the direct and indirect effects test can be seen in the following table:

Table 1 Path Coefficients

\begin{tabular}{|c|c|c|c|}
\hline & T Statistics (|O/STDEV|) & P Values & Signification \\
\hline Financial Literacy (X1) -> Saving Behavior (Y) & 1,261 & 0,208 & Rejected \\
\hline Financial Inclusion (X2) -> Saving Behavior (Y) & 0,079 & 0,937 & Rejected \\
\hline Financial Attitude (X3) -> Saving Behavior (Y) & 2,514 & 0,012 & Accepted \\
\hline X1*Self Control (M) -> Saving Behavior $(Y)$ & 1,008 & 0,314 & Rejected \\
\hline X2* Self Control (M) -> Saving Behavior (Y) & 0,455 & 0,649 & Rejected \\
\hline X3* Self Control (M) -> Saving Behavior $(Y)$ & 1,295 & 0,196 & Rejected \\
\hline
\end{tabular}


Naca Perangin-angin et.al. The effect of financial literacy, financial inclusion and financial attitude on saving behavior with self control as moderation: study on households in Cingkes Village, Dolok Silau District, Simalungun Regency.

\section{DISCUSSION \\ Effect of Financial Literacy on Saving Behavior}

The probability value of this study if the prob value $<0.05$ or tstatistics $>$ ttable then the proposed hypothesis is accepted. In table 4.16 explains the results of hypothesis testing from this study, it shows that the financial literacy variable has no significant effect on saving behavior which states the value of tstatistics < ttable (1.988) which is 1.261. This states that the first hypothesis of financial literacy has a positive and significant effect on the saving behavior of households in Cingkes Village, which is rejected. The results of this study are in line with research conducted by (Sekarwati \& Susanti, 2020) that financial literacy has no effect on saving behavior. Financial literacy emphasizes the importance of applying knowledge and skills in finance in making financial decisions (Atkinson \& Messy, 2011). Financial knowledge also includes the ability and skills to calculate interest, investment returns, fines and so on (Laily, 2016).

\section{Effect of Financial Inclusion on Saving Behavior}

The probability value of this study if the prob value $<0.05$ or tstatistics $>$ ttable then the proposed hypothesis is accepted. In table 4.16 explains the results of hypothesis testing from this study, it shows that the financial inclusion variable has no significant effect on saving behavior which states the value of tstatistics < ttable (1.988) which is 0.079 . This states that the second hypothesis of financial inclusion has a positive and significant effect on the saving behavior of households in Cingkes Village, which is rejected. The results of this study are in line with research conducted by (Ahdan, 2020) that financial inclusion has no effect on saving behavior. Financial Inclusion is a program intended to make the public understand and use the services of financial institutions, especially banking (Kumar, 2013). The World Bank also explains that financial inclusion is a condition where most people can take advantage of available financial services and provide education to community groups who are not aware of the benefits of access to finance through access that is available without high costs (World Bank, 2014).

\section{Effect of Financial Attitude on Saving Behavior}

The probability value of this study if the prob value $<0.05$ or tstatistics $>$ ttable then the hypothesis is accepted. Table 4.16 explains the results of hypothesis testing from this study, which shows that the financial attitude variable has a significant positive and significant effect on saving behavior which states the value of tstatistics $<$ ttable (1.988) which is 2.514. This states that the third hypothesis that financial attitude has a positive and significant effect on the saving behavior of households in Cingkes Village is accepted. The results of this study are in line with research conducted by (Seong et al., 2011) that financial attitude has a positive and significant influence on saving behavior. Attitude refers to how a person feels about personal financial matters, which is measured by the response to a statement or opinion (Marsh, 2006). Financial Attitude is one of the factors that influence the behavior of each individual, meaning that the financial attitude of the average respondent is followed by good saving behavior. The better the financial attitude of the household, the better the saving behavior will be.

\section{Effect of Financial Literacy on Saving Behavior with Self Control as Moderation}

Based on the test results, the hypothesis of this study shows that the financial literacy variable has no significant effect on saving behavior with self control as moderating which states the value of tstatistics < ttable (1.988) which is 1.008 . The results of the study explain that the selfcontrol variable is not able to moderate the influence of financial literacy on saving behavior. This states that the fifth 
Naca Perangin-angin et.al. The effect of financial literacy, financial inclusion and financial attitude on saving behavior with self control as moderation: study on households in Cingkes Village, Dolok Silau District, Simalungun Regency.

hypothesis of self-control moderating the influence of financial literacy on the saving behavior of households in Cingkes Village is rejected.

This study is in line with research (Mardiana \& Rochmawati, 2020) where financial knowledge is not moderated by self-control on saving behavior. The purpose of financial literacy is as a basic need for every individual to avoid financial problems (Krisna et al., 2010), financial errors can arise due to errors in financial management. So that self-control research does not moderate financial knowledge on saving behavior, because households with good self-control will be careful in managing their finances so that they can be saved.

\section{Effect of Financial Inclusion on Saving Behavior with Self Control as moderation}

Based on the test results, the hypothesis of this study shows that the financial inclusion variable has no significant effect on saving behavior with self control as moderating which states the value of tstatistics < ttable (1.988) which is 0.455 . The results of the study explain that the self-control variable cannot moderate the effect of financial inclusion on saving behavior. This states that the sixth hypothesis of self-control moderating the effect of financial inclusion on the saving behavior of households in Cingkes Village is rejected. Access to financial institutions is not a barrier for households to set aside income for savings, but because households have good self-control the household can still have good saving behavior because the Cingkes Village household decides to save at the Credit Cooperative located in Cingkes Village.

\section{Effect of Financial Attitude on Saving Behavior with Self Control as moderating}

Based on the test results, the hypothesis of this study shows that the financial attitude variable has no significant effect on saving behavior with self control as moderating which states the value of tstatistics < table (1.988) which is 1.295. The results of the study explain that the selfcontrol variable cannot moderate the influence of financial attitude on saving behavior. This states that the fifth hypothesis of self-control moderating the influence of financial attitude on the saving behavior of households in Cingkes Village is rejected. A good level of financial attitude tends to have wiser financial behavior (Mien $\&$ Thao, 2015). A better financial attitude will result in making various decisions related to better financial management as well. Each household has a different attitude towards financial behavior, so attitudes affect household saving behavior.

\section{CONCLUSION}

Based on the results of research and discussion, the following conclusions can be drawn:

1. Financial Literacy has no significant effect on Saving Behavior of household in Cingkes Village.

2. Financial Inclusion has no significant effect on the Saving Behavior of households in Cingkes Village.

3. Financial Attitude has a positive and significant effect on Saving Behavior of household in Cingkes Village.

4. Self Control is not significant as a moderator of the relationship between Financial Literacy and Saving Behavior of household in Cingkes Village.

5. Self Control is not significant as a moderator of the relationship between Financial Inclusion and Saving Behavior of household in Cingkes Village.

6. Self Control is not significant as a moderator of the relationship between Financial Attitude and Saving Behavior of household in Cingkes Village.

Acknowledgement: None

Conflict of Interest: None

Source of Funding: None 
Naca Perangin-angin et.al. The effect of financial literacy, financial inclusion and financial attitude on saving behavior with self control as moderation: study on households in Cingkes Village, Dolok Silau District, Simalungun Regency.

\section{REFERENCES}

1. Ahdan. (2020). Pengaruh Literasi Keuangan dan Inklusi keuangan terhadap Perencanaan Keuangan Masyarakat Palembang. Skripsi.

2. Ardiana, M. (2016). Kontrol Diri, Pendidikan Pengelolaan Keuangan Keluarga, Pengetahuan Inklusi Keuangan Siswa Pengaruhnya Terhadap Perilaku Menabung Siswa SMK Se Kota Kediri. Jurnal Ekonomi Pendidikan Dan Kewirausahaan, 4(1).

3. Azlan, A., Jamal, A., Kamal, W., Mohdrahimie, R., Roslemohidin, A. K., \& Osman, Z. (2015). The Effects of Social Influence and Financial Literacy on Savings Behavior: A Study on Students of Higher Learning Institutions in Kota Kinabalu, Sabah. International Journal of Business and Social Science, 6(111), 110-119.

4. Budiono, T. (2015). Keterkaitan Financial Attitude, Financial Behavior, dan Financial Knowledge Pada Mahasiswa Strata 1 Universitas Atmajaya Yogyakarta. Universitas Atmajaya Yogyakarta.

5. Dixit, R. (2013). Financial Inclusion For Inclusive Growth of India: A Study of Indian States. International Jurnal of Business Management Research, 3.

6. Gaisina, S., \& Kaidarova, L. (2017). Financial Literacy of Rural Population as a Determinant of Saving Behavior in Kazakhstan. Rural Sustainability Research, 38(333), $32-42$. https://doi.org/10.1515/plua-2017-0010

7. Ghozali, I. (2015). Konsep, Teknik dan Aplikasi Menggunakan Aplikasi SmartPLS 3.0 (Edisi 2). Badan Penerbit Universitas Diponegoro.

8. Ghufron, M. N., \& Rini, R. S. (2012). TeoriTeori Psikologi. Ar-Ruzz Media.

9. Herdjiono, I., \& Damanik, L. A. (2016). Pengaruh Financial Attitude,Financial Knowledge, Parental Income Terhadap Financial Management Behavior. Jurnal Manajemen Teori Dan Terapan| Journal of Theory and Applied Management, 9(3), 226-241.

https://doi.org/10.20473/jmtt.v9i3.3077

10. Humaira, I., \& Sagoro, E. M. (2018). Pengaruh Pengetahuan Keuangan, Sikap Keuangan, Dan Kepribadian Terhadap Perilaku Manajemen Keuangan Pada Pelaku Umkm Sentra Kerajinan Batik Kabupaten Bantul. Nominal, Barometer Riset Akuntansi Dan Manajemen, https://doi.org/10.21831/nominal.v7i1.1936 3

11. Indonesia, B. (2016). Booklet Perbankan Indonesia 2016. https://www.ojk.go.id/id/kanal/perbankan/d ata-dan-statistik/booklet-perbankanindonesia/Documents/Pages/BookletPerbankan-Indonesia-2016/Booklet Perbankan Indonesia 2016.pdf

12. Jennifer, \& Pamungkas, A. S. (2021). Pengaruh Self Control, Financial Literacy Dan Parental Socialization Terhadap Saving Behavior. Jurnal Manajerial Dan Kewirausahaan, III(1), 8-15.

13. Khairuni, N. (2016). Dampak Positif Dan Negatif Sosial Media Terhadap Pendidikan Akhlak Anak (Studi Kasus Di Smp Negeri 2 Kelas Viii Banda Aceh). Jurnal Edukasi: Jurnal Bimbingan Konseling, 2(1), 91. https://doi.org/10.22373/je.v2i1.693

14. Kumar, N. (2013). Financial inclusion and its determinants: evidence from India. Journal of Financial Economic Policy, 5(1), 4-19.

https://doi.org/https://doi.org/10.1108/17576 381311317754

15. Laily, N. (2016). Pengaruh Literasi Keuangan Terhadap Perilaku Mahasiswa Dalam Mengelola Keuangan. Journal of Accounting and Business Education, 1(4). https://doi.org/10.26675/jabe.v1i4.6042

16. Mardiana, V., \& Rochmawati. (2020). Self Control Sebagai Moderasi Antara Pengetahuan Keuangan, Financial Attitude, Dan Uang Saku Terhadap Perilaku Menabung. Jurnal Pendidikan Ilmu Sosial, $3(2)$.

17. Margaretha, F., \& Pambudh, R. A. (2015). Tingkat Literasi Keuangan Pada Mahasiswa S-1 Fakultas Ekonomi. Jurnal Manajemen Dan Kewirausahaan, 17(1), 76-85. https://doi.org/10.9744/jmk.17.1.76

18. Marsh, B. A. (2006). Examining The Personal Finance Attitudes, Behaviors, And Knowledge Levels Of First-Year And Senior Students At Baptist Universities In The State Of Texas. August.

19. Mien, N. T. N., \& Thao, T. P. (2015). Factors Affecting Personal Financial Management Behaviors: Evidence from Vietnam. Paper Presented to AP15Vietnam Conference.

20. Morgan, P. J., \& Long, T. Q. (2020). Financial literacy, financial inclusion, and savings behavior in Laos. Journal of Asian 
Naca Perangin-angin et.al. The effect of financial literacy, financial inclusion and financial attitude on saving behavior with self control as moderation: study on households in Cingkes Village, Dolok Silau District, Simalungun Regency.

Economics,

68.

https://doi.org/10.1016/j.asieco.2020.10119 7

21. OECD. (2018). OECD/INFE Toolkit for Measuring Financial Literacy and Financial Inclusion. In Oecd (Issue March).

22. Ozili, P. K. (2018). Impact of digital finance on financial inclusion and stability. Borsa Istanbul Review, 18(4), 329-340. https://doi.org/10.1016/j.bir.2017.12.003

23. Pankow, D. (2003). Financial Values. Attitudes and Goals. Fargo, North Dakota: North Dakota University.

24. Purnami, R. S. (2013). Pengaruh Kepuasan Kerja Dan Komitmen Organisasional Terhadap Kewarganegaraan Organisasional Serta Implikasinya Terhadap Kinerja Pegawai Administrasi Politeknik Komputer Niaga Lpkia Bandung. Skripsi, Universitas Pendidikan Indonesia.

25. Putra, E. D., \& Sari, R. (2020). Pengetahuan Inklusi Keuangan Terhadap Perilaku Menabung Karyawan. 10(1), 01016.

26. Remund, D. L. (2010). Financial literacy explicated: The case for a clearer definition in an increasingly complex economy. Journal of Consumer Affairs, 44(2), 276$295 . \quad$ https://doi.org/10.1111/j.17456606.2010.01169.x

27. Sekarwati, M. A., \& Susanti. (2020). Pengaruh literasi keuangan, inklusi keuangan dan modernitas individu terhadap perilaku menabung mahasiswa perguruan tinggi negeri surabaya. Journal of Economic, 16(2), 268-275. http://journal.feb.unmul.ac.id/index.php/IN OVASI

28. Sirine, H., \& Utami, D. S. (2016). FaktorFaktor Yang Memengaruhi Perilaku Menabung Di Kalangan Mahasiswa. Jurnal Ekonomi Dan Bisnis, 19(1). https://doi.org/https://doi.org/10.24914/jeb.v 19i1.479
29. Sugiyono. (2017). Metode Penelitian Kuantitatif, Kualitatif, dan $R \& D$. Alfabet.

30. Thung, C. M., Kai, C. Y., Nie, F. S., Chiun, L. W., \& Tsen, T. C. (2012). Determinants Of Saving Behaviour Among The University Students In Malaysia.

31. Triani, M. (2017). No Analisis Saving Behaviour pada Mahasiswa SI di Kota PadangTitle.

32. Wahid, N. (2014). Keuangan Inklusif: Membongkar Hegemoni Keuangan. Gramedia.

33. Wardani, P. D., \& Susanti. (2019). Pengaruh Kontrol Diri, Religiusitas, Literasi Keuangan, Inklusi Keuangan Terhadap Perilaku Menabung Di Bank Syariah Mahasiswa Universitas Islam Negeri Sunan Ampel Surabaya. Jurnal Pendidikan Akuntansi, 7(2), 189-196.

34. Yasid, M. (2010). Perilaku Menabung Ibu Rumah Tangga Keluarga mustahik' Peserta Program Ikhtiar Lembaga Keuangan Mikro Syariah Berbasis Kelompok di Bogor, Jawa Barat. Islamic Financial \& Business Review, 4(1). https://doi.org/10.30993/tifbr.v4i1.32

35. Zulaika, M. D. S., \& Listiadi, A. (2020). Literasi Keuangan, Uang Saku, Kontrol Diri, dan Teman Sebaya Terhadap Perilaku Menabung Mahasiswa. Ekuitas: Jurnal Pendidikan Ekonomi, 8(2), 137-146. https://ejournal.undiksha.ac.id/index.php/E $\mathrm{KU}$

How to cite this article: Naca Perangin-angin, Khaira Amalia Fachrudin, Nisrul Irawati. The effect of financial literacy, financial inclusion and financial attitude on saving behavior with self control as moderation: study on households in Cingkes Village, Dolok Silau District, Simalungun Regency. International Journal of Research and Review. 2022; 9(1): 470-477. DOI: https://doi.org/10.52403/ijrr.20220153 